\title{
Sensitivitas Pemeriksaan CT-Scan pada pasien dengan Coronavirus Disease 2019 (Covid-19)
}

\author{
Muhammad F. H. Putra, ${ }^{1}$ Vonny N. Tubagus, ${ }^{2}$ Yovana P. M. Mamesah ${ }^{2}$
}

${ }^{1}$ Program Studi Pendidikan Dokter Fakultas Kedokteran Universitas Sam Ratulangi, Manado, Sulawesi Utara, Indonesia

${ }^{2}$ Bagian Radiologi Fakultas Kedokteran Universitas Sam Ratulangi/RSUP Prof. Dr. R. D. Kandou Manado, Sulawesi Utara, Indonesia

Email: faizalhidayah09@gmail.com

\begin{abstract}
COVID-19 is an infectious disease caused by SARS-CoV-2 virus that has become a health problem worldwide, including Indonesia. The SARS-CoV-2 was identified in the early 2020. For current diagnostic procedures, RT-PCR is considered as the gold standard in COVID19 detection. However, there is another alternative method which is the chest CT-scan that can supports the diagnosis of COVID-19 faster. This study was aimed to determine the sensitivity of the CT scan in COVID-19 patients. This was a literature review study using three databases, as follows: Pubmed, ClinicalKey, and Google Scholar. The keywords used were sensitivity AND CT scan AND COVID-19. After being selected based on inclusion and exclusion criteria, 10 literatures would be discussed. The results showed that the sensitivity of the CT scan among COVID-19 patients was quite good and had a sensitivity percentage ranging 70-90\%. In comparison with the RT-PCR examination, the CT scan results are quite good. CT scan has a high sensitivity to COVID-19 and has a better result compared to the RT-PCR test.
\end{abstract}

Keywords: sensitivity of test, CT scan, COVID-19

\begin{abstract}
Abstrak: COVID-19 merupakan penyakit infeksi yang disebabkan oleh SARS-CoV-2 yang telah menjadi masalah kesehatan di dunia, termasuk di Indonesia. SARS-CoV-2 baru teridentifikasi pada awal tahun 2020. Untuk prosedur diagnostik saat ini, RT-PCR dianggap sebagai standar baku emas dalam deteksi COVID-19. Namun terdapat metode lain yaitu pemeriksaan CT scan toraks yang merupakan tes alternatif cepat untuk dilakukan dan dapat membantu menegakkan diagnosis COVID-19. Penelitian ini bertujuan untuk mengetahui sensitivitas dari pemeriksaan CT scan pada COVID-19. Jenis penelitian ialah literature review dengan pencarian data menggunakan tiga database yaitu Pubmed, ClinicalKey, dan Google Scholar. Kata kunci yang digunakan yaitu sensitivity AND CT scan AND COVID-19. Setelah diseleksi berdasarkan kriteria inklusi dan eksklusi, didapatkan 10 literatur yang dibahas dalam penelitian ini. Hasil penelitian menunjukkan bahwa sensitivitas pemeriksaan CT scan pada COVID-19 cukup baik dan memiliki rentang persentase sensitivitas 70-90\%. Pada perbandingan dengan pemeriksaan RT-PCR didapatkan hasil yang cukup baik untuk pemeriksaan $C T$ scan. Pemeriksaan CT Scan memiliki nilai sensitivitas yang cukup tinggi pada COVID-19 dan lebih baik dibandingkan RT-PCR.
\end{abstract}

Kata kunci: sensitivitas tes, CT scan toraks, COVID-19

\section{PENDAHULUAN}

Coronavirus disease 2019 (COVID-19) merupakan penyakit infeksi oleh virus yang telah menjadi masalah kesehatan di dunia, termasuk di Indonesia. Penyakit yang disebabkan oleh Severe Acute Respiratory
Syndrome Coronavirus 2 (SARS-CoV-2) baru teridentifikasi pada awal tahun $2020 .^{1}$ Berdasarkan website WHO, data terkini per tanggal 16 Desember didapatkan total jumlah kasus COVID-19 di seluruh dunia ialah sekitar 71,919,725 kasus positif yang 
terkonfirmasi dan 1,623,064 kasus kematian yang terkonfirmasi penyebab COVID-19 yang diperoleh dari 216 negara yang terindikasi pandemik COVID-19. ${ }^{2}$ Tercatat pada tanggal 16 Desember 2020, Indonesia melaporkan kasus terkonfirmasi COVID-19 pertama hingga data terbaru yang menunjukkan kasus telah mencapai angka 629,429 dengan kasus kematian akibat COVID-19 sebanyak 19,111 kasus. ${ }^{3}$

Untuk prosedur diagnostik saat ini, reverse-transcription ion polymerase chain reaction (RT-PCR) dianggap sebagai standar baku emas dalam deteksi COVID19. Mengingat keadaan darurat global saat ini, sensitivitas variabel RT-PCR dan waktu tunggu yang lama untuk hasil menyiratkan bahwa banyak pasien yang terjangkit COVID-19 mungkin tidak dapat diidentifikasi, sehingga mempertaruhkan perparahan infeksi yang lebih lebih lanjut pada populasi sehat. Chest computed tomography (Chest CT) atau pemeriksaan CT scan toraks merupakan tes alternatif cepat untuk dilakukan dan dapat membantu dalam diagnosis COVID-19, terutama dalam situasi laboratorium yang sangat dibanjiri oleh pemeriksaan RT-PCR saat ini. ${ }^{4}$

Penelitian oleh Xie et $\mathrm{al}^{5}$ melaporkan bahwa terdapat lima dari 167 pasien (3\%) pernah teridentifikasi RT-PCR negatif untuk COVID-19 pada presentasi awal meskipun terdapat temuan khas dari pneumonia virus pada pemeriksaan CT scan toraks. ${ }^{5,6}$ COVID-19 telah ditetapkan oleh WHO sebagai pandemi yang memerlukan ketepatan penenegakan diagnosis segera; hal ini yang mendorong penulis untuk menelusuri sensitivitas pemeriksaan CT scan toraks pada COVID-19 serta membandingkannya dengan pemeriksaan RT-PCR.

\section{METODE PENELITIAN}

Penelitian ini dilaksanakan dalam bentuk suatu literature review mengenai sensitivitas pemeriksaan CT scan pada COVID-19. Data yang diperoleh dalam penelitian ini merupakan berbagai hasil penelitian, artikel atau jurnal nasional dan internasional yang diterbitkan selama tahun 2020. Pencarian data di internet menggunakan database dari ClinicalKey, Google Scholar, PubMed, dan berbagai sumber literatur lainnya. Kata kunci yang digunakan yaitu COVID-19 AND CT Scan AND sensitivity. Pencarian data juga dilakuikan berdasarkan tersedianya abstrak dan fulltext dari sebuah literatur. Setelah melakukan seleksi berdasarkan kriteria inklusi dan eksklusi didapatkan 10 artikel penelitian yang dibahas.

\section{HASIL PENELITIAN}

Berdasarkan 10 artikel penelitian yang telah diperoleh, didapatkan data persentase nilai sensitivitas CT scan pada pasien yang terindikasi positif COVID-19. Tabel 1 memperlihatkan persentase nilai sensitivitas $C T$ scan masing-masing literatur yang dikaji dalam penelitian ini.

Tabel 1. Data persentase nilai sensitivitas CT scan masing-masing literatur.

\begin{tabular}{cllc}
\hline $\begin{array}{c}\text { Nomor } \\
\text { literatur }\end{array}$ & \multicolumn{1}{c}{ Penulis } & \multicolumn{1}{c}{$\begin{array}{c}\text { Asal } \\
\text { Negara }\end{array}$} & $\begin{array}{c}\text { Sensitivitas } \\
\text { CT } \text { scan toraks }\end{array}$ \\
\hline 1 & He et al & China & $79 \%$ \\
2 & Ai et al & China & $97 \%$ \\
3 & Long et al $^{9}$ & China & $97,2 \%$ \\
4 & Fang et al $^{10}$ & China & $98 \%$ \\
5 & Wang et al $^{11}$ & China & $96,5 \%$ \\
6 & Dangis et al $^{12}$ & Belgium & $86,7 \%$ \\
7 & Falaschi et al $^{13}$ & Italia & $90,7 \%$ \\
8 & Fu et al $^{14}$ & China & $85,9 \%$ \\
9 & Himoto et al $^{15}$ & Jepang & $100 \%$ \\
10 & Wen et al $^{16}$ & China & $93 \%$ \\
\hline
\end{tabular}


Hasil penelitian dari literatur ke-1 oleh $\mathrm{He}$ et al, $2020^{7}$ di China mendapatkan bahwa dari 34 pasien saat melakukan pemeriksaan awal RT-PCR sebanyak 27 orang memiliki hasil positif COVID-19 sedangkan hasil pemeriksaan dari CT scan toraks mendapatkan hasil positif COVID-19 pada 26 pasien. Dengan demikian nilai sensitivitas RT-PCR berada di persentase $79 \%$ sedangkan $C T$ scan toraks memiliki nilai persentase $77 \%$. Nilai spesifitas RT-PCR yaitu $100 \%$ dan CT scan toraks $96 \%$ sedangkan untuk nilai akurasi PCR yaitu $92 \%$ dan CT scan toraks $88 \%$.

Hasil penelitian dari literatur ke-2 oleh Ai et al, $2020^{8}$ di China mendapatkan hasil dari 1014 pasien terdapat 601 yang positif COVID-19 dengan pemeriksaan RT-PCR dan 580 dari 601 tersebut mendapatkan hasil $C T$ scan toraks positif. Untuk hasil negatif didapatkan sejumlah 413 dari hasil pemeriksaan RT-PCR; 308 dari 413 tersebut mendapatkan hasil positif pada pemeriksaan CT scan toraks.

Hasil penelitian dari literatur ke-3 oleh Long et al, $2020^{9}$ di China mendapatkan hasil dari 36 kasus COVID-19 disertai pneumonia dan pada pemeriksaan $C T$ scan toraks didapatkan 35 pasien memiliki hasil CT scan abnormal. Hasil pemeriksaan RTPCR mendapatkan 30 pasien positif COVID-19 sehingga hal tersebut menghasilkan nilai sensitivitas pemeriksaan $C T$ scan toraks sekitar 97,2\% dan RT-PCR sekitar 84,6\%.

Hasil penelitian dari literatur ke-4 oleh Fang et al, $2020^{10}$ di China mendapatkan perbedaan hasil positif COVID-19 yaitu dari 51 pasien pada awal pemeriksaan, 36 memiliki hasil positif pada pemeriksaan RTPCR sedangkan pada pemeriksaan $C T$ scan toraks didapatkan 50 pasien memiliki hasil abnormal, 36 pasien (72\%) memiliki gambaran manifestasi tipikal sedangkan 14 pasien $(28 \%)$ memiliki gambaran manifestasi atipikal sehingga untuk nilai sensitivitas pemeriksaan CT scan sekitar $98 \%$.

Hasil penelitian dari literatur ke-5 oleh Wang et al, $2020^{11}$ di Jepang mendapatkan hasil dari 114 orang, hanya 3 orang saja yang tidak memperlihatkan hasil abnormal pada pemeriksaan $C T$ scan toraks dan 1 pasien yang memperlihatkan adanya dilatasi pada bagian tengah kanan dan bawah paru namun tak menunjukkan abnormalitas lainnya. Semua pasien lainnya menunjukkan abnormalitas pada hasil pemeriksaannya. Dari hasil tersebut didapatkan sensitivitas pemeriksaan $C T$ scan toraks sekitar $96,5 \%$.

Hasil penelitian dari literatur ke-6 oleh Dangis et al, 2020 12 di Belgia mendapatkan dari 192 pasien yang dilakukan pemeriksaan CT scan dosis rendah (Low Dose Sub Millisievert $C T$ scan) didapatkan nilai sensitivitas $86,7 \%$, spesifitas $93,6 \%$, dan akurasi $90,2 \%$ yang telah dibandingkan dengan RT-PCR.

Hasil penelitian dari literatur ke-7 oleh Falaschi et al, $2020^{13}$ yang melakukan penelitian pada masa epidemi di Italia pada 773 pasien dengan pemeriksaan $C T$ scan toraks dan telah dilakukan beberapa prosedur lainnya sehingga mendapatkan data hasil sensitivitas dari pemeriksaan $C T$ scan toraks itu sendiri sekitar 90,7\%, spesifitas 78,8\%, dan akurasi 85,9\%.

Hasil penelitian dari literatur ke-8 oleh Fu et al, $2020^{14}$ di China mendapatkan hasil dari 64 pasien, 58 diantaranya memiliki temuan abnormal pada pemeriksaan $C T$ scan toraks. CT scan pertama (dalam 2 hari) memiliki sensitivitas yang lebih tinggi dari RT-PCR dalam mendeteksi COVID-19 yaitu sekitar $85,9 \%$ untuk $C T$ scan toraks dan 56,3\% untuk RT-PCR.

Hasil penelitian dari literatur ke-9 oleh Himoto et al, $2020^{15}$ mendapatkan hasil dari 21 pasien yang sudah terkonfirmasi positif COVID-19, semuanya memiliki gambaran hasil CT scan toraks yang abnormal (GGO bilateral, limfadenopati mediastinal, efusi pleura, dll) sehingga didapatkan hasil persentase sensitivitas $C T$ scan toraks sebesar $100 \%$.

Hasil penelitian dari literatur ke-10 oleh Wen et al, $2020^{16}$ mendapatkan hasil dari 103 pasien yang dalam pengawasan, didapatkan 86 pasien $(85 \%)$ pasien positif COVID-19, sedangkan untuk hasil pemeriksaan $C T$ scan toraks dari 88 pasien yang 
positif hasil RT-PCR didapatkan 82 orang memiliki hasil abnormal sehingga nilai sensitivitas dari pemeriksaan $C T$ scan toraks sekitar $93 \%$.

\section{BAHASAN}

Berdasarkan hasil kajian literaturliteratur penelitian yang telah dijelaskan, didapatkan bahwa pemeriksaan $C T$ scan toraks pada COVID-19 memiliki sensitivitas yang baik dan bahkan pada beberapa penelitian, persentase nilai sensitivitas mencapai nilai $98-100 \% \cdot 10,15$ Hal ini bisa menjadi tolak ukur bahwa pemeriksaan $C T$ scan bisa dijadikan salah satu metode dalam menilai kondisi seseorang yang telah terinfeksi COVID-19.

Pada penelitian oleh $\mathrm{He}$ et $\mathrm{al}^{7}$ dilakukan proses pembandingan hasil pemeriksaan RT-PCR dan $C T$ scan toraks dalam mendiagnosis COVID-19 pada 82 pasien yang dirawat. Setelah melakukan pemeriksaan RT-PCR didapatkan 34 positif dan 48 negatif COVID-19. Pada pemeriksaan awal RT-PCR didapatkan sebanyak 27 pasien positif dan 7 pasien dalam pengawasan dari total 34 pasien yang diatas. Hasil pemeriksaan $C T$ scan toraks dari 34 pasien yang telah dirawat tersebut sebelumnya telah menunjukkan sebanyak 26 pasien memiliki hasil $C T$ scan positif untuk COVID-19 dan 6 pasien memiliki normal sehingga tidak didapatkan perbedaan hasil secara statistik pada kedua pemeriksaan tersebut. ${ }^{7}$

Berbeda halnya dengan penelitian oleh Fang et al ${ }^{10}$ yang mendapatkan dari 51 pasien diperoleh 15 pasien yang mendapatkan hasil negatif untuk pemeriksaan RTPCR namun hasil positif untuk pemeriksaan CT scan toraks. Ketika ditotalkan jumlahnya dengan pasien yang positif untuk kedua pemeriksaan tersebut didapatkan bahwa $C T$ scan memiliki sensitivitas yang lebih tinggi yaitu sekitar 50 orang atau $98 \%$ dibandingkan RT-PCR yang hanya dapat mendeteksi 36 orang saja. ${ }^{10}$ Angka ini malah menunjukkan terdapat perbedaan bermakna antara $C T$ scan dan RT-PCR dibandingkan penelitian sebelumnya. Menurut Fang, ${ }^{10}$ alasan yang menyebabkan hasil deteksi asam nukleat virus memiliki efektifitas rendah yaitu perkembangan teknologi pendeteksian asam nukleat yang belum matang; variasi dalam tingkat deteksi dari produsen yang berbeda; viral load pasien yang rendah, atau pengambilan sampel klinis yang tidak tepat.

Pemeriksaan RT-PCR dan CT scan toraks efektif dalam skrining cepat COVID19. Kombinasi pemeriksaan RT-PCR dan CT scan toraks dapat dilakukan jika salah satu pemeriksaan negatif. ${ }^{7}$ Keuntungan $C T$ scan toraks untuk mendeteksi COVID-19 pada pasien bergejala dengan sensitivitas yang lebih tinggi dan pada periode waktu awal infeksi ini cukup penting dan harus dijelaskan lebih lanjut dalam studi prospektif. ${ }^{10,12}$

\section{SIMPULAN}

Tingkat sensitivitas dari pemeriksaan CT scan toraks pada COVID-19 baik dalam menentukan diagnosis dan tingkat keparahan dari COVID-19. Tingkat sensitivitas dari $C T$ scan toraks dibandingkan dengan RTPCR pada beberapa penelitian mendapatkan hasil yang lebih baik namun CT scan toraks masih belum disarankan sebagai modalitas utama pada COVID-19.

Disarankan bahwa terkait dengan topik ini, perlu dilakukan penelitian lebih mendalam juga untuk kasus-kasus COVID-19 yang terjadi di Indonesia mengingat masih sangat kurang penelitian mengenai topik ini di Indonesia. Selain itu, perlu dilakukan penelitian dan pengembangan mengenai topik ini lebih lanjut dikarenakan topik ini masih terbilang cukup baru dan masih banyak penelitian selanjutnya yang akan dilakukan di masa depan sehingga tidak menutup kemungkinan hasil dan simpulan penelitian ini akan berbeda dengan hasil terbaru.

\section{Konflik Kepentingan}

Penulis menyatakan tidak terdapat konflik kepentingan dalam studi ini.

\section{DAFTAR PUSTAKA}

1. World Health Organization. Origin of SARSCoV-2. [Internet]. World Health Organization. 2020 [cited 2020 Dec 16]. 
Available from:https://www.who.int/ publications-detail/origin-of-sars-cov-2

2. World Health Organization. WHO Coronavirus disease (COVID-19) Dashboard [Internet]. World Health Organization. 2020 [cited 2020 Dec 16]. Available from: https://covid19.who.int/

3. World Health Organization. Coronavirus disease 2019 (COVID-19) Situation report. [Internet]. World Health Organization. 2020 [cited 2020 Dec 16]. Available from: https://www.who.int/ docs/default-source/coronaviruse/ situation-reports/20200423-sitrep-94covid-19.pdf

4. Kementerian Kesehatan RI. Pedoman dan Pencegahan Coronavirus (COVID-19) (Revisi ke-5). Jakarta, 2020; p.1-214.

5. Xie X, Zhong Z, Zhao W, Zheng C, Wang F, Liu J, et al. Chest CT for typical 2019. nCoV pneumonia: relationship to negative RT-PCR testing. Radiology. 2020; 296:E41-E45.

6. Young D, Tatarian L, Mujtaba G, Chow P, Ibrahim S, Joshi G, et al. Chest CT versus RT-PCR for diagnostic accuracy of COVID-19 detection: a meta-analysis search results. J Vasc Med Surg. 2020; 8(3):3-4. doi.org/10.35248/2329-6925. 20.8.392.Copyright

7. He J, Luo L, Luo Z, Liu J, Ng M, Shen X et al. Diagnostic performance between CT and initial real-time RT-PCR for clinically suspected 2019 coronavirus disease (COVID-19) patients outside Wuhan, China. Respir Med. 2020;168: 105980. doi.org/10.1016/j.rmed.2020. 105980

8. Ai T, Yang Z, Hou H, Zhang C, Chen C, Xia L et al. Correlation of Chest CT and RTPCR testing in coronavirus disease 2019 (COVID-19) in China: A Report of 1014 Cases. Radiology. 2020;296(2): E32-E40. doi/10.1148/radiol.20202006 42

9. Long C, Xu H, Shen Q, Zhang X, Fan B, Wang $\mathrm{C}$ et al. Diagnosis of the coronavirus disease (COVID-19): rRT-PCR or CT?
Eur J Radiol. 2020;126. doi.org/10. 1016/j.ejrad.2020.108961

10. Fang Y, Zhang H, Xie J, Lin M, Ying L, Pang $P$ et al. Sensitivity of chest CT for COVID-19: Comparison to RT-PCR. Radiology. 2020;296:E115-7. doi.org/ 10.1148/radiol.2020200432

11. Wang K, Kang S, Tian R, Zhang X, Wang Y. Imaging manifestations and diagnostic value of chest $\mathrm{CT}$ of coronavirus disease 2019 (COVID-19) in the Xiaogan area. Clin Radiol. 2020;75:341-7. doi.org/10. 1016/j.crad.2020.03.004

12. Dangis A, Gieraerts C, De BY, Janssen L, Valgaeren H, Obbels D et al. Accuracy and reproducibility of low-dose submillisievert chest $\mathrm{CT}$ for the diagnosis of COVID-19. Radiol Cardiothorac Imaging. 2020;2(2):e200196. doi/10. 1148/ryct.2020200196

13. Falaschi Z, Danna P, Arioli R, Pasché A, Zagaria D, Percivale I, et al. Chest CT accuracy in diagnosing COVID-19 during the peak of the Italian epidemic: a retrospective correlation with RT-PCR testing and analysis of discordant cases. Eur J Radiol. 2020;130:5-9. doi.org/10. 1016/j.ejrad.2020.109192

14. Fu L, Gao Y, Zhou K, Luo M, Ma P, Song F et al. Clinical and CT imaging characteristics of COVID-19 cases in Wenzhou city: a retrospective analysis. Research Square. 2020:1-20. doi.org/10.21203/ rs.3.rs-18096/v1

15. Himoto Y, Sakata A, Kirita M, Hiroi T, Kenji $\mathrm{K}$, Hyunjin $\mathrm{K}$ et al. Diagnostic performance of chest CT to differentiate COVID-19 pneumonia in non-highepidemic area in Japan. Jpn J Radiol. 2020;38(5):400-6. doi.org/10.1007/ s11604-020-00958-w

16. Miao C, Jin M, Miao L, Yang X, Huang P, Xiong $\mathrm{H}$, et al. Early chest computed tomography to diagnose COVID-19 from suspected patients: A multicenter retrospective study. Am J Emerg Med. 2020;S0735-6757(20)30281-3. doi:10.1016/j.ajem.2020.04.051 